\title{
Originals
}

\section{Prevalence of Diabetes Mellitus, Coronary Heart Disease and Hypertension in the Families of Insulin Dependent and Insulin Independent Diabetics}

\author{
A. S. Królewski, A. Czyżyk, J. Kopczyński and S. Rywik \\ Departments of Gastroenterology and Metabolic Diseases and of Epidemiology, Warsaw Medical Academy \\ and Institute of Food and Nutrition in Warsaw, Poland
}

Summary. During an epidemiological study concerning the fate of diabetics in Warsaw, 2,356 subjects (aged 35-68 years with duration of diabetes mellitus of 3-11 years) were investigated with particular relevance to the presence of diabetes mellitus, coronary heart disease, and hypertension in their parents and siblings. Diabetics were classified into the following groups: insulin dependent, insulin independent nonobese, insulin independent obese, and a group in whom the distinction between insulin dependence and insulin independence was unclear. The findings in these groups were compared with the frequencies of these diseases in a random sample of the general population. There was an excess of diabetes in close relatives of all the diabetic groups. This was highest for insulin independent non-obese diabetics. There was no difference in the prevalence of coronary heart disease and hypertension in close relatives of insulin dependent diabetics when compared with the general population, but these were twice as prevalent in close relatives of the insulin independent non-obese group. Obese insulin independent diabetics reported a similar excess of coronary heart disease and hypertension in siblings, but the excess was less marked in parents. The prevalence of these diseases in families of probands with unclassified diabetes was intermediate between the other two groups. These results demonstrate an aggregation of diabetes mellitus with coronary heart disease and hypertension in families of insulin independent non-obese diabetics. This provides further evidence for heterogeneity in diabetes mellitus.

Key words: Insulin dependent diabetes, insulin independent diabetes, familial occurrence of diabetes mellitus, familial occurrence of coronary heart disease, familial occurrence of hypertension.
Evidence has accumulated in recent years which suggests that diabetes is a heterogeneous disease with differing aetiologies [1-5]. Among factors contributing to this hypothesis was data showing different aggregations of diabetes when defined by clinical characteristics. These came mainly from comparisons of groups of diabetics classified by the age of onset and non-diabetics $[1,6,7]$. Only one study has compared insulin dependent diabetics with insulin independent diabetics of the same age [8] and very few studies have considered the familial occurrence of diseases other than diabetes.

In this study, an attempt has been made to assess whether patients with different clinical types of adult diabetes, have differences in the familial occurrences of diabetes, coronary heart disease and arterial hypertension.

\section{Patients and Methods}

Part of a large epidemiological study on the fate of diabetics in Warsaw provided data on the occurrence of various non-communicable diseases in the families of diabetics $[9,10]$. Five thousand Warsaw residents with diabetes diagnosed during the period 1963-1973 were recruited. Diagnosis required a blood glucose level of at least $7.8 \mathrm{mmol} / \mathrm{l}$ either in the fasting state, or $2 \mathrm{~h}$ after a meal or oral administration of glucose. In the present study, conducted in $1973-74$, a subgroup of the above study were selected according to the following criteria: age 35-68 years, onset after the 30th birthday and duration of diabetes 3-11 years. Out of the total group 2,356 satisfied these criteria ${ }^{1}$.

Each diabetic proband was interviewed and examined by a group of specially trained research assistants according to a standard protocol [9]. The probands were asked whether any of their first degree relatives had been treated for diabetes, hypertension or coronary heart disease (angina pectoris, myocardial infarction or death due to myocardial infarction). In addition, the ages of first degree relatives were recorded at the time of study if alive, or at death if deceased. Probands were also asked about the occurrence

\footnotetext{
${ }_{1}$ Detailed tables according to the age of the studied probands are available from the authors
} 
Table 1. Characteristics of probands according to various clinical types of diabetes

\begin{tabular}{|c|c|c|c|c|c|c|}
\hline \multirow{3}{*}{$\begin{array}{l}\text { Characteristics } \\
\text { of probands }\end{array}$} & \multicolumn{6}{|c|}{ Clinical types of diabetes } \\
\hline & \multicolumn{3}{|c|}{ Age $35-54$ years } & \multicolumn{3}{|c|}{ Age $55-68$ years } \\
\hline & $\begin{array}{l}\text { Insulin } \\
\text { dependent } \\
n=146(73)^{\mathrm{a}} \\
(\%)\end{array}$ & $\begin{array}{l}\text { Insulin } \\
\text { independent } \\
n=430(225) \\
(\%)\end{array}$ & $\begin{array}{l}\text { Unclassified } \\
n=166(87) \\
(\%)\end{array}$ & $\begin{array}{l}\text { Insulin } \\
\text { dependent } \\
n=106(60)^{\mathrm{a}} \\
(\%)\end{array}$ & $\begin{array}{l}\text { Insulin } \\
\text { independent } \\
n=1182 \\
(688)^{\mathrm{a}} \\
(\%)\end{array}$ & $\begin{array}{l}\text { Unclassified } \\
n=326(205)^{\mathrm{a}} \\
(\%)\end{array}$ \\
\hline \multicolumn{7}{|l|}{ At the time of diagnosis of diabetes } \\
\hline $\begin{array}{l}\text { Diagnosis made during } \\
\text { the first } 6 \text { months } \\
\text { since onset of symptoms }\end{array}$ & 80.3 & 52.7 & 59.3 & 65.3 & 57.8 & 60.8 \\
\hline $\begin{array}{l}\text { Insulin treatment from } \\
\text { diagnosis of diabetes }\end{array}$ & 92.4 & 0.7 & 35.3 & 82.1 & 0.3 & 35.7 \\
\hline \multicolumn{7}{|l|}{ At the time of present study } \\
\hline Relative weight $110 \%$ or more & 18.6 & 57.7 & 52.7 & 41.8 & 57.4 & 49.4 \\
\hline Treatment with insulin & 97.2 & 1.2 & 53.3 & 89.6 & - & 48.5 \\
\hline $\begin{array}{l}\text { Father alive and aged } 65 \\
\text { years or more or died } \\
\text { after } 65 \text { years }\end{array}$ & 42.0 & 49.0 & 50.4 & 41.5 & 47.0 & 42.0 \\
\hline $\begin{array}{l}\text { Mother alive and aged } 65 \\
\text { years or more or died } \\
\text { after } 65 \text { years }\end{array}$ & 56.5 & 62.0 & 65.6 & 57.5 & 62.0 & 56.5 \\
\hline
\end{tabular}

a Number of women in parentheses

of diabetes in their spouses. Interviewers took a careful history of clinical presentation and subsequent treatment of diabetes.

The following subgroups of diabetics were defined according to the reported mode of treatment. Insulin dependent diabetes: insulin throughout the entire duration of the disease. (If the patient was ever taken off insulin, the period off had to be less than 6 months.) Insulin independent diabetes: oral agents or diet throughout the entire duration of the disease. (If the patient was ever put on insulin, the period on insulin had to be less than 6 months.) Unclassified diabetes mellitus: oral agents or diet and insulin at different periods. (Patients who did not meet either of the criteria above because they had been treated by both modes of therapy for longer than 6 months each). The probands with insulin independent diabetes were subdivided into non-obese ( $<110 \%$ relative body weight $)$ and obese diabetics $(110 \%$ or $>$ relative body weight). Relative body weights were calculated using sex, age, and height specific means for a random sample of the population of a large city in Poland [11].

Similar data on the frequency of diabetes, hypertension and coronary heart disease in first degree relatives were available from a study of the prevalence of cardiovascular diseases [12]. In that study a random sample of the population aged $30-54$ years was interviewed using the same questionnaire by trained interviewers using the same protocol.

The frequency of each studied disease in the parents, siblings and spouses was calculated as follows. The numerator was the number of probands, not the number of relatives, so that a positive response indicates that either parent or both were known to have the disease; similarly for siblings, one or more was known to have the disease. Probands who did not know about the occurrence of a particular disease in the parents or siblings, or who were uncertain, were excluded from the calculation for that disease. The prevalence of various diseases among parents was independent of age of probands until 55 years and thereafter clearly declined, so for the purpose of analysis, the probands were divided into two subgroups according to their age: $35-54$ and $55-68$ years. The results of the study were subjected to statistical analysis using the Chi square test.

\section{Results}

Table 1 shows the characteristics of the probands. At the time of the study the insulin dependent diabetic probands had the lowest proportion of obese individuals. In contrast, the prevalence of obesity was highest in the insulin independent diabetic probands. The proportion of obese individuals in the unclassified diabetic group was similar to the insulin independent subgroup. In the unclassified diabetic subgroup, 35\% of probands were treated with insulin initially and were subsequently treated with oral agents for a minimum of 6 months. The remaining unclassified diabetic probands were treated with oral drugs or diet initially, but later they required insulin treatment for 6 months or more. At the time of the study almost half of these patients were treated with insulin. All subgroups of diabetic probands in both age groups had a similar proportion of parents who had attained the age of 65 years. The proportion for fathers ranged from 40 to $50 \%$, while for mothers it ranged from 55 to $65 \%$.

Table 2 shows the prevalence of a history of diabetes in families according to age and type of diabetes in probands. In general, the prevalence of diabetes increased with age in siblings and spouses, but decreased in parents. A parental history of diabetes was more commonly reported by insulin independent diabetics than insulin dependent diabetic probands. When the insulin independent diabetic probands 
Table 2. Frequency of diabetes mellitus in families of probands with various types of diabetes mellitus

\begin{tabular}{|c|c|c|c|c|c|c|c|c|}
\hline \multirow{3}{*}{$\begin{array}{l}\text { Type of diabetes } \\
\text { mellitus }\end{array}$} & \multicolumn{8}{|c|}{ Age of diabetic probands } \\
\hline & \multirow[t]{2}{*}{$\begin{array}{l}\text { No. of } \\
\text { probands }\end{array}$} & \multicolumn{3}{|c|}{$\begin{array}{l}35-54 \text { years } \\
\text { Probands reported } \\
\text { diabetes among }(\%)\end{array}$} & \multirow[t]{2}{*}{$\begin{array}{l}\text { No. of } \\
\text { probands }\end{array}$} & \multicolumn{3}{|c|}{$\begin{array}{l}\text { 55-68 years } \\
\text { Probands reported } \\
\text { diabetes among }(\%)\end{array}$} \\
\hline & & Parents & Siblings & Spouses & & Parents & Siblings & Spouse \\
\hline Insulin dependent & 143 & $12.6^{\mathrm{d}}$ & $7.0^{\mathrm{d}}$ & 2.2 & 100 & $5.0^{\mathrm{d}}$ & $8.0^{\mathrm{d}}$ & $2.2^{\mathrm{d}}$ \\
\hline Insulin independent & 415 & 19.8 & 7.5 & 2.5 & 1080 & 7.2 & 13.4 & 4.2 \\
\hline (relative body weight $<110 \%$ ) & 171 & $23.4^{\mathrm{d}}$ & $7.6^{\mathrm{d}}$ & 2.9 & 462 & $10.4^{\mathrm{e}}$ & $13.0^{\mathrm{d}}$ & 4 \\
\hline (relative body weight $>110 \%$ ) & 244 & 17.3 & 7.4 & 2.2 & 618 & 4.9 & 13.8 & 4 \\
\hline Unclassified & 162 & 19.8 & 4.3 & 3.7 & 304 & 8.9 & 15.5 & 3.1 \\
\hline $\begin{array}{l}\text { Random sample of normal } \\
\text { population }^{\mathrm{b}}\end{array}$ & 955 & 2.4 & 0.7 & - & - & - & - & - \\
\hline \multicolumn{9}{|c|}{$\begin{array}{l}\text { a } 22 \text { diabetics ( } 3 \%) \text { did not know about diabetes in their families and were omitted } \\
\text { b } 104 \text { individuals }(8 \%) \text { did not know about diabetes in their families and were omitted } \\
\text { c } 130 \text { diabetics }(10 \%) \text { did not know about diabetes in their families and were omitted } \\
\text { d } \text { NS } \\
\text { e } p<0.001\end{array}$} \\
\hline
\end{tabular}

Table 3. Frequency of coronary heart disease in families of probands with various types of diabetes mellitus

\begin{tabular}{|c|c|c|c|c|c|c|}
\hline \multirow{3}{*}{ Type of diabetes mellitus } & \multicolumn{6}{|c|}{ Age of diabetic probands } \\
\hline & \multirow[t]{2}{*}{$\begin{array}{l}\text { No. of } \\
\text { probands }^{\mathrm{a}}\end{array}$} & \multicolumn{2}{|c|}{$\begin{array}{l}35-54 \text { years } \\
\text { Probands reported } \\
\text { coronary heart disease among }(\%)\end{array}$} & \multirow[t]{2}{*}{$\begin{array}{l}\text { No. of } \\
\text { probands }^{c}\end{array}$} & \multicolumn{2}{|c|}{$\begin{array}{l}55-68 \text { years } \\
\text { Probands reported } \\
\text { coronary heart disease among }(\%)\end{array}$} \\
\hline & & Parents & Siblings & & Parents & Siblings \\
\hline Insulin dependent & 139 & $5.8^{\mathrm{e}}$ & $2.9^{\natural}$ & 92 & $4.4^{\mathrm{d}}$ & $4.4^{\mathrm{d}}$ \\
\hline Insulin independent & 382 & 16.2 & 7.8 & 976 & 8.0 & 8.7 \\
\hline (relative body weight $<110 \%$ ) & 158 & $20.9^{f}$ & $5.1^{\mathrm{d}}$ & 412 & $8.5^{\mathrm{d}}$ & $9.5^{\mathrm{d}}$ \\
\hline (relative body weight $>110 \%$ ) & 224 & 13.0 & 9.8 & 564 & 7.6 & 8.2 \\
\hline Unclassified & 157 & 10.2 & 1.9 & 278 & 11.5 & 10.8 \\
\hline $\begin{array}{l}\text { Random sample of normal } \\
\text { populations }\end{array}$ & 954 & 11.2 & 1.8 & - & - & - \\
\hline \multicolumn{7}{|c|}{$\begin{array}{l}64 \text { diabetics }(9 \%) \text { did not know about coronary heart disease in their families and were omitted } \\
105 \text { individuals }(10 \%) \text { did not know about coronary heart disease in their families and were omitted } \\
\text { c } 268 \text { diabetics }(17 \%) \text { did not know about coronary heart disease in their families and were omitted } \\
\text { d } \\
\text { e } p<0.001 \\
p<0.05\end{array}$} \\
\hline
\end{tabular}

were separated according to relative body weight, an excess of probands with diabetes in parents was found in the non-obese group (body weight $<110 \%$ ). Thus, in a comparison of non-obese insulin independent diabetics with insulin dependent diabetic probands, the difference was statistically significant $(p<0.025)$ for the younger probands. For the older probands where the prevalences were lower, the difference was not significant $(p<0.10)$. With regard to diabetic history in siblings and spouses, the prevalences were similar in insulin dependent diabetics and insulin independent diabetic probands, regardless of their relative body weight. The unclassified diabetic probands had a pattern of prevalences which roughly paralleled the insulin independent diabetic probands.
Comparison of diabetic probands with the general population sample showed that the prevalence of diabetes among the parents and siblings of the former groups was from five to ten times that of the general population $(p<0.001)$. In Poland in the 1970's symptomatic diabetes diagnosed by doctors was reported in $1.3 \%$ of individuals of a random adult population sample (unpublished data), while symptomatic and asymptomatic diabetes diagnosed by the EASD Epidemiology Study Group criteria was found in $2.3 \%$ of a random sample of adults from a large Polish city [13]. It would seem that the prevalence of diabetes mellitus in spouses of probands was similar to the prevalence observed in the general population.

The prevalences of coronary heart disease in the 
Table 4. Frequency of hypertension in families of probands with various types of diabetes mellitus

\begin{tabular}{|c|c|c|c|c|c|c|}
\hline \multirow{3}{*}{$\begin{array}{l}\text { Type of diabetes } \\
\text { mellitus }\end{array}$} & \multicolumn{6}{|c|}{ Age of diabetic probands } \\
\hline & \multirow[t]{2}{*}{$\begin{array}{l}\text { No. of } \\
\text { probands }\end{array}$} & \multicolumn{2}{|c|}{$\begin{array}{l}35-54 \text { years } \\
\text { Probands reported } \\
\text { hypertension among }(\%)\end{array}$} & \multirow[t]{2}{*}{$\begin{array}{l}\text { No. of } \\
\text { probands }\end{array}$} & \multicolumn{2}{|c|}{$\begin{array}{l}55-68 \text { years } \\
\text { Probands reported } \\
\text { hypertension among }(\%)\end{array}$} \\
\hline & & Parents & Siblings & & Parents & Siblings \\
\hline Insulin dependent & 120 & $22.5^{\mathrm{e}}$ & $4.2^{\mathrm{d}}$ & 76 & $11.8^{\mathrm{d}}$ & $11.8^{\mathrm{d}}$ \\
\hline Insulin independent & 332 & 34.0 & 8.4 & 787 & 17.0 & 15.6 \\
\hline (relative body weight $<110 \%$ ) & 135 & $37.1^{\mathrm{d}}$ & $8.2^{\mathrm{d}}$ & 350 & $18.6^{\mathrm{d}}$ & $13.1^{\mathrm{d}}$ \\
\hline (relative body weight $>110 \%$ ) & 197 & 32.0 & 8.7 & 437 & 15.8 & 17.6 \\
\hline Unclassified & 144 & 32.6 & 4.9 & 219 & 15.1 & 14.2 \\
\hline $\begin{array}{l}\text { Random sample of normal } \\
\text { population }^{\mathrm{b}}\end{array}$ & 837 & 20.8 & 2.1 & & - & - \\
\hline \multicolumn{7}{|c|}{$\begin{array}{l}\text { a } 146 \text { diabetics }(20 \%) \text { did not know about hypertension in their families and were omitted } \\
\text { b } 222 \text { individuals }(21 \%) \text { did not know about hypertension in their families and were omitted } \\
\text { c } 532 \text { diabetics }(33 \%) \text { did not know about hypertension in their families and were omitted } \\
\text { d NS } \\
\text { e } p<0.001\end{array}$} \\
\hline
\end{tabular}

families is shown in Table 3 according to age and type of diabetes in probands. As before, the prevalences of probands with a history of coronary heart disease in siblings increased with their age, with the converse trend for parents. In general, the prevalence of coronary disease history among siblings as well as parents was higher in insulin independent diabetics than insulin dependent diabetic probands at all ages. The differences were only statistically significant in the younger age group. When the insulin independent diabetic probands were separated according to relative body weight, the prevalence of parental coronary disease history was seen to be highest $(20.9 \%)$ in the younger group of lean insulin independent diabetic probands. This was significantly higher than that found in the heavier insulin independent diabetic probands. This difference was quite opposite to findings in siblings of the younger group and no differences at all were found in the older group of probands. Comparison of the unclassified diabetic probands with insulin dependent diabetics and insulin independent diabetic probands revealed an inconsistent relationship. In the younger group the prevalences were very similar to those in the insulin dependent diabetic probands and to those found in the population sample while in the other group they resembled the insulin independent diabetic probands. Comparison of the non-obese insulin independent diabetic group with the general population revealed significant differences in the parental and sibling histories $(p<0.01)$.

The prevalence of a history of hypertension in the family members of the diabetic probands is shown in Table 4. In general, the prevalences were higher than those for the other two diseases. Once again, the prevalence was higher for the siblings of older probands and lower for their parents. The prevalence of a family history of hypertension was higher for insulin independent diabetics than insulin dependent diabetic probands. This difference was largest and was statistically significant for parental history among the younger probands. Other differences were not significant. Comparison of the unclassified diabetic probands with the insulin dependent diabetics and insulin independent diabetic probands revealed, except for siblings in the young group, the same pattern seen in insulin independent diabetic subjects. In all but insulin dependent diabetic probands, the prevalence of hypertension in relatives was higher than in the general population $(p<0.01)$.

\section{Discussion}

The results of this study provide evidence for different degrees of aggregation of diabetes, coronary heart disease and hypertension in families of probands with different types of diabetes mellitus.

The most interesting finding was the high prevalence of a family history of diabetes, coronary heart disease and hypertension among insulin independent non-obese probands. This finding in a population based study cannot be explained on the basis of selection; thus a common background, genetic as well as environmental, linking these three diseases should be considered. Such a common background could explain the co-existence of diabetes and atherosclerotic complications so frequently observed by many authors [14-16]. A few other data sources suggest this possibility. In the studies conducted in Tecumseh, 
subjects aged $30-49$ years with an elevated blood glucose level reported coronary disease and deaths caused by this disease among their parents more frequently than subjects with a normal blood glucose level [17]. The authors also found a much higher prevalence of diabetes mellitus among males whose fathers had coronary heart disease before the age of 65 years than in males whose fathers were healthy or developed coronary heart disease, after the age of 65 years [18]. Hypercholesterolaemia, a risk factor for coronary heart disease, has been reported to be more frequent among male offspring of diabetic parents than among the offspring of non-diabetic parents [19]. Furthermore, in the Israeli Ischaemic Heart Disease Project [20] blood pressure, serum cholesterol and the presence of cardiovascular disease were found to be significant independent variables for predicting subsequent development of diabetes during a five year follow-up of middle-aged men. Moreover, two studies have reported a positive correlation between blood glucose levels and arterial blood pressure within individuals [21, 22].

The fact that the prevalence of diabetics among spouses of diabetic probands was independent of the type of diabetes and was similar to that for a screened sample from the general population suggests that the environment shared by probands and spouses plays an insignificant role in the development of this disease.

The prevalence of the above diseases in families of probands aged between 30 and 49 years was higher than in those aged between 50 and 65 years. This may reflect, in part, the development of health care in Poland. On the other hand, it may indicate a decreasing influence of genetic background with age of the proband as has been previously reported [23]. A similar pattern has been noted for coronary heart disease [18].

Acknowledgements. This investigation was supported in part by the Research Grant 10-RMZ-1 from the Polish Ministry of Health and Welfare. The authors wish to thank Dr. J. H. Warram, Joslin Research Laboratory, Joslin Diabetes Center, Boston, Mass., USA for his assistance and comments during the preparation of this paper.

\section{References}

1. Ganda OI, Soeldner JS (1977) Genetic acquired and related factors in the aetiology of diabetes mellitus. Arch Intern Med 137: $461-469$

2. Cudworth AG(1978) Type I diabetes mellitus, Diabetologia 14: 281-291

3. Rotter JI, Rimoin DL (1978) Heterogeneity in diabetes mellitus - Updata 1978. Evidence for further genetic heterogeneity within juvenile-onset insulin-dependent diabetes mellitus. Diabetes 27:599-605

4. Fajans SS, Cloutier MC, Crowther RL (1978) Clinical and aetiological heterogeneity of idiopathic diabetes mellitus. Diabetes 27: 1112-1125
5. Rotter JI, Rimoin DL (1979) Diabetes mellitus: the search for genetic markers. Diabetes Care 2: 215-226

6. Tattersall RB, Pyke DA (1972) Diabetes in identical twins. Lancet $2: 1120-1125$

7. MacDonald MJ (1974) Equal incidence of adult-onset diabetes among ancestors of juvenile diabetics and non-diabetics. Diabetologia 10:767-773

8. Tattersall RB, Fajans SS (1975) A difference between the inheritance of classical juvenile-onset and maturity onset type diabetes of young people. Diabetes 24: 44-53

9. Czyżyk A, Brzezinski ZJ, Królewski AS, Janeczko D, Wysocki M, Puncewicz B (1975) Losy chorych na cukrzyce I. Plan baden, metody i grupa badana. Przegl Epidemiol 29:449-459

10. Królewski AS, Czyżyk A, Janeczko D, Kopczyński J (1977) Mortality from cardiovascular diseases among diabetics. Diabetologia $13: 345-350$

11. Kopczyński J (1972) Height of adults in Cracow. II Weight for height. Epidemiol Rev 26:379-387

12. Mikolajczyk W, Liszewska-Pfeifer D, Rywik S, Korewicki J, Szczypiorowski B, Wagrowska H (1978) Chorobowośći zapadalnośé na chorobę wieńcowạ w dlugofalowych badaniach ludności Plocka i Sochaczewa. Przegl Lek 35:873-78

13. Mroszczyk M, Gdulewicz T, Torzecka W, Jurga-Waniek K, Loba J (1976) Cukrzyca w próbie losowej trzech dzielnic Lodzi. Zdrow Publiczne 87: 169-174

14. Wahlberg F (1966) Intravenous glucose tolerance in myocardial infarction, angina pectoris and intermittent claudication. Acta Med Scand 180 (Suppl): 7-93

15. Ostrander LD Francis T, Hayner NS, Kjelsberg MD, Epstein FH (1965) The relationship of cardiovascular diseases to hyperglycaemia. Ann Intern Med 62: 1188-1198

16. Ipsen J, Clark TC, Elsom KO, Roberts NJ (1969) Diabetes and heart disease: periodic health examination programs. Am J Publ Health 59: 1595-1612

17. Deutscher S, Epstein FH, Keller JB (1969) Relationship between familial aggregation of coronary heart disease and risk factors in the general population. Am J Epidemiol 89: 510-520

18. Deutscher S, Ostrander LD, Epstein FH (1970) Familial factors in premature coronary heart disease - a preliminary report from Tecumseh community health study. Am J Epidemiol 91: 233-237

19. Kyner JL, Levy RI, Soeldner JS, Gleason RE, Fredrickson DS (1976) Lipid, glucose, and insulin interrelationships in normal, prediabetic, and chemical diabetic subjects. J Lab Clin Med 88: 345-358

20. Medalie JH, Papier CM, Goldbourt U, Herman JB (1975) Major factors in the development of diabetes mellitus in 10,000 men. Arch Intern Med 135: 811-817

21. Stamler J, Rhomberg P, Schoenberger JA, Sheklle RB, Dyer A, Sheklle S, Stamler R, Wannamaker J (1975) Multivariate analysis of the relationship of seven variables to blood pressure. $J$ Chron Dis 28: $527-548$

22. Jarrett RJ, Keen H, McCartney M, Fuller JH, Hamilton PJS, Reid DD, Rose G (1978) Glucose tolerance and blood pressure in two population samples: their relation to diabetes mellitus and hypertension. Intern J Epidemiol 7: 15-24

23. Simpson NE (1969) Heritabilities of liability to diabetes when sex and age at onset are considered. Ann Hum Genet 32: 283-303

Received: 19 May 1980

and in revised form: 22 June 1981

Andrzej S. Królewski, M.D.

Department of Epidemiology

Warsaw Medical Academy

ul.Oczki 3

PL-02-007 Warsaw, Poland 